\title{
Erratum to: A Framework for Quantifying Qualitative Responses in Pairwise Experiments
}

\section{A. H. Al-lbrahim ${ }^{1}$}

Published online: 14 August 2019

(C) The Classification Society 2019

\section{Erratum to: Journal of Classification https://doi.org/10.1007/s00357-019-09337-1}

The original version of this article unfortunately contained a mistake in Title and reference Thurstone, L. L. (1927).

The Title should be "A Framework for Quantifying Qualitative Responses in Pairwise Experiments".

The correct reference should only be presented as "Thurstone, L. L. (1927). A law of comparative judgment. Psychological Review, 34, 273-286." deleting the statement that comes after this.

The original article has been corrected.

Publisher's Note Springer Nature remains neutral with regard to jurisdictional claims in published maps and institutional affiliations.

The online version of the original article can be found at https://doi.org/10.1007/s00357-019-09337-1

\section{A. H. Al-Ibrahim}

1 Safat, Kuwait 